\title{
Electric power supply, main source and backing: A survey of residential utilization features
}

\author{
Azodo, Adinife Patrick $\square$ \\ Federal University of Agriculture, Abeokuta, Nigeria (azodopat@gmail.com)

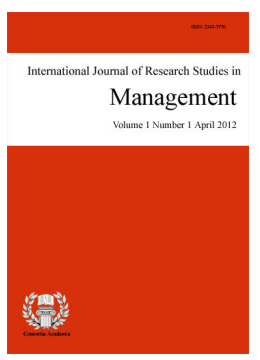

Accepted: 27 September 2014

ISSN: 2243-7770 Online ISSN: 2243-7789

OPEN ACCESS

\section{Abstract}

Limited access to quality and quantity electricity has remained an unresolved scourge in Nigeria. The ravage cuts across all electric energy utilization sectors in the nation especially the residential sector. This study highlights the sources of electric power supply, utilization features and effects of electricity deficits in Obantoko residents. A total of 124 households interviewed were selected using systematic random sampling techniques. This comprises of room(s), flat and duplex apartment inhabitants. The findings showed that despite the national grid connection, a significant number of households own and operate generators due to electricity shortfalls in the area. Comparative analysis of electricity supply status with that of countries in Southeast Asia such as India, Bangladesh, and Pakistan revealed that power supply deficit is a cognizant issue in developing countries. This essentially hampers domestic activities in the residential sectors. The effects on several households includes interruption of work, home discomfort, consequential effect on performance, increase expenditure, undue wastage, stress due to manual/mechanical household works and enjoyment/pleasure disruption. The salvaging role of private generators as an alternative source of power supply does not seem to significantly address the problem of electric power insufficiency in Nigeria as it poses its own challenges. There is therefore the need for improvement of the public source of power supply and adoption of other private alternative sources of electricity supply that have reduced operating cost and health implication.

Keywords: electricity; household; energy; consumption; source 


\section{Electric power supply, main source and backing: A survey of residential utilization features}

\section{Introduction}

Electricity has over the decade become extensively used in all areas of human endeavour viz administrative, industrial, commercial, and residential areas. Records of established sections where the involvement of electricity has presumed a norm ranges from homes, health care delivery, social services, industry, education, agriculture through to defense and of course in some nations, transportation (Olokooba, Ibrahim, \& Abdulraheem-Mustapha, 2010). Energy supply has become the next important ingredient for living after air and water (Abayomi, 2012). A considerable number of studies found in literature buttressed that electricity is one of the most important basic necessities for living (Azodo \& Adejuyigbe, 2013; Bhagavan, 1999; Isola, 2007; Louw, Craigwell, \& Moore, 2008; Makoju, 2002; Narayan \& Smyth, 2005; Narayan, Smyth, \& Prasad, 2007; Nasir, Tariq, \& Arif, 2008).

Among industrial, commercial and residential electricity consumption sectors, residential utilizations have been observed to have the highest share of electricity consumption, which also varies with location (Ekpo, 2010; Ali-Akpajiak \& Pyke, 2003; Oseni \& George, 2012; Central Bank of Nigeria, 2009). Statistical analysis of electricity consumption (Mega Watts per h) in Nigeria which covers from 1970 - 2004 showed that electricity consumption in the residential sector has consistently dominated other sectors from 1978 (Ekpo, Chuku, \& Effiong, 2011). Ekpo, Chuku, \& Effiong (2011) also observed that as residential electricity consumption rises, the industrial sector continues to fall. Domestic activities such as cooking, refrigerating, washing, ironing, lighting, entertainment, air conditioning, pumping of water etc., involves the use of electricity. Of the total electricity consumption in homes, kitchen, laundry appliances, preservation devices, lighting and home electronics are the main electricity users in a household (Herath, Gebremedhin, \& Fletcher, 2011). Pelesai and ThankGod (2013) stated that Nigerians increasingly buy electrical appliances to consume the power (energy) produced by different sources such as national power grid, chemical batteries, generators and solar panels. Residential electricity consumption has a number of varying factors contributing to the quantity of electricity used by each household, such as income, price of electricity, degree of urbanization and population variables (Adegbulugbe \& Akinbami, 1995; Arimah, 1992; Hickling, 2006; Holtedahl \& Joutz, 2000, 2004; Lin \& Quising, 2003; Xiaohua \& Zhenmin, 2001).

Other factors such as household size, age distribution of home residents, and climatic condition of an area also contribute to the household's electricity consumption (Halvorsen \& Larsen, 1999; Ubani, Umeh, \& Ugwu, 2013; Yoo, Lee, \& Kwak, 2007; Joskow, 2008; Hondroyannis, Swamy, Tavlas, \& Hall, 2010; Ekpo, Chuku, \& Effiong, 2011). Sule, Ajao, and Ajimotokan (2011) added that the substantial energy utilization witnessed in household sector is caused by considerable energy loss attributable to the use of incandescent lamp.

\subsection{Consumption characteristic of electricity in homes}

Residential electricity consumption has remained among the numerous sectors that contribute to the top hierarchy of electric power usage. The number of equipment and appliances owned by a household differs significantly from that of another as well as in their respective utilization characteristics (Reiss \& White, 2002). Individual household demand for electricity is a service derived demand from using different number of appliances and equipment (Ekpo, Chuku, \& Effiong, 2011; Reiss \& White, 2002). Appraisal of residential electricity consumption showed that almost half of household electricity is used for lighting, television, radio, air conditioning, refrigeration, ironing, and so on. With the rapid advancements in technological innovations alongside the growth in the domestic electric appliance industry, there seems to be no complete domestic task that does not involve the use of an electrically operated device in one way or the other. EPSERP (2009) added 
that a considerable proportion of residential electricity consumed in Nigeria is by women through household chores and other non-residential activities.

The involvement of electricity in domestic chores has unreserved advantages in saving time, reduction of stress and energy conservation compared to the manual/mechanical processes. Middle and high-income consumers in urban areas together make up substantial residential electricity consumers. This consumer-class typically uses several household appliances and items that consume much electric power, such as fridges, air conditioners, electric cookers, water heaters coupled with substantial amounts of light in their homes (RCEER, 2005) where the large remaining residential consumers use electric power for lighting (RCEER, 2005). Over time, as the number of households grows, lifestyle change, more electric appliances are acquired (RCEER, 2005, Ekpo, Chuku, \& Effiong, 2011). It is expected that the quantity of electricity generated will also change to keep up with the load. Odularu and Okonkwo (2009) found out that as the real gross domestic product grows so does electricity consumption. Typical challenges with residential electricity is its continuous demand and usage, much of which is in the morning and evening hours, besides the other less consumption periods of the day. This poses difficulties in the provision of electricity in the residential sector (Mulyono, 2013; RCEER, 2005).

\subsection{Quality and quantity of accessible electricity in Nigeria}

The power sector of Nigeria is marked by its erratic nature, frequent interruption, total blackout, insufficient power supply, etc. Power outages for about 26 days per month, which last eight hours per day experienced in Nigeria is relatively worse than the regional and world average records (Moyo, 2012). 9\% sales lost due to these disruptions and an average of about $97.1 \%$ of ownership and operation of private generators by business firms located in Nigeria explain the severity of power problems in the nation (Ali-Akpajiak \& Pyke, 2003; Moyo, 2012). Wastage challenges encountered between the generation and distribution points, especially where installed capacities are far below transmitted plays pivotal role in the quantity and quality of accessible power in Nigeria (Babatunde \& Shuaibu, 2009; Ubi, Effiom, Okon \& Oduneka, 2012). Kazeem (2013) echoed that Nigeria has one of the highest transmission losses in the world with a record of $35 \%$ loss. The recent daily electricity loss recorded is about 2,993.7 megawatts (MW) (Oketola, 2014). There have been several plans and projections to address the power insufficiency in the country; unfortunately the nation has never met any of her past energy demand projections.

Electric power transmission and distribution losses in Nigeria covering 1971 - 2010 showed that Nigeria had her highest loss value of $49.27 \%$ of the output in 1981 and the lowest in 2009 with a value of $5.87 \%$ of the output. While the power transmission and distribution loss in kilowatt hour is 8.085 billion $\mathrm{kWh}$ in 2002 for maximum and a minimum value of 0.25 billion $\mathrm{kWh}$ in 1971 (indexmundi.com, 2013). Different administrations in Nigeria had witnessed this inadequate power generation and distribution challenges (Uzoma, Nnaji, \& Nnaji, 2012).

According to ECN (2005) several billion dollars of public investment has in the past decade gone into electricity generation and transmission capacity expansion, unfortunately the outcome contrasts sharply with the extremely frequent electric power interruption and voltage variation. Popoola, Ponnle, and Ale (2011) revealed that the quality of electricity in Nigeria is below $10 \%$. This meager supply of electricity in Nigeria as against the ever increasing demand of the same has been a great challenge to the nation. The World Bank and some foreign organizations report on countries with electricity access deficit revealed that Nigeria is the second worst in electricity shortage. The report stated that 82.4 million out of the nation's population of 160 million people lack access to electricity (Tokede \& Okonji, 2013). It was estimated that the supply shortfall is about $80 \%$ of the country's potential electricity demand (Gnansounou, 2008). The total Installed capacity from both thermal and hydro electricity generating plants in Nigeria in 1999 was 5,860 MW and an available capacity of 5,400 MW while the effective capacity was about $1600 \mathrm{MW}$.

Ten years after (2009) the total installed capacity of the generating plants rose to 7,876 MW out of which 
about 4,000 MW constituted available capacity and effective average daily generated capacity below 2,700 MW. In 2012 a peak of 4,517 MW was attained which latter dropped to 3,443 MW in 2013 (Oketola, 2013). The recent installed capacity is about 10,000 MW within which available capacity of 6,668.6 MW was generated, where effective capacity of 3,400 MW or so is actually generated daily (Oketola, 2014). The challenges of electricity in Nigeria could be put as an outcome of technology, poor maintenance culture, old and insufficient installations, infrastructural decay, vandalism of electrical installations, fire incidents, poor funding, low tariffs, huge debts owed the electricity industry, irregularity of stream flow, power loss experienced from generation to distribution points due to distance of generation point to the distribution and inaccurate forecast of electricity consumption determinants and patterns especially from its regional perspective (Oseni \& George, 2012; Ubani, Umeh, \& Ugwu, 2013; Odularu \& Okonkwo, 2009; Ubi et al., 2012; Oketola, 2014; Asaolu \& Oladele, 2006; World Bank, 2004; Sule, 2010; Adenikinju, 2003)

\subsection{Power supply potentials in Nigeria}

Nigeria as a nation is enormously endowed with large quantity of non-renewable and renewable primary sources of energy which if properly and substantially harnessed will achieve stability in energy supply to the nation. The country has estimated natural gas reserves of 185 trillion cubic feet, 35 billion barrels of crude oil and 2.75 billion metric tons of coal reserves (Ubi et al., 2012; Uzoma, Nnaji, \& Nnaji, 2012; ECN, 2002; Ibitoye \& Adenikinju, 2007; Iwayemi, 2008a; Anaekwe, 2010). According to Uzoma, Nnaji, and Nnaji (2012) Nigeria is capable of producing an estimated total exploitable large-scale hydropower potential of 36,000 $\mathrm{GWh}$ of electricity annually. The daily electrical energy obtainable from the sun in Nigeria expressed in barrel is equivalent to 4.66 million barrels of oil per day (Sambo, 2005). Other energy resources available for boosting electricity in Nigeria include wind energy $2.0-4.0 \mathrm{~m} / \mathrm{s}$, biomass 144 million tons/year and wave and tidal energy $150,000 \mathrm{TJ} /(16.6$ x 106 toe/yr) (Ibitoye \& Adenikinju, 2007). All these massive primary energy resources for the generation of electricity in the country notwithstanding, Nigeria currently depends on gas-fired thermal and hydropower stations for electricity generation (Ayodele, 1999; Sanyaolu, 2008; Okoro \& Chikuni, 2007; Simolowo \& Oladele, 2012) as a consequence, creating a very wide gap between the electricity generated and the demand in the nation.

\subsection{Prevalence of generators in residential sector}

Erratic power supply and prolonged power outages experienced in the nation has grossly encouraged a significant percentage of residential and other non-residential electricity consumers to seek alternative sources of power supply (Iwayemi, 2008b; Odularu, \& Okonkwo, 2009). In the event of power outages, private generating plants aid continuation of important electrical appliances where halting will severely affect activities (Azodo \& Adejuyigbe, 2013). A large number of households, especially those residing in urban areas, though the figure are uncertain; rely on generators for their electricity needs. Estimated figures from the Global Business Intelligence in 2011 revealed that Nigerians spent about four hundred and fifty five million dollars on generators (Oketola, 2014). The wide spread substitution of private for public provision of electricity explains why the residential electricity consuming class has taken over the electricity consumption leadership in Nigeria. Power interruption challenges for residential consumers are associated with some latent variables such as inconveniences, interference and disruption of housekeeping or leisure activities. Odularu and Okonkwo (2009) reiterated that electricity is necessary for the realization of uninterrupted comfort. The appalling part of owning and operating private generators includes its relative high operation cost, considerable power insufficiency and the accompanied health issue.

\subsection{Power shortage: a conventionality or peculiarity}

Electricity demand and supply mismatch is a widespread challenging issue. Most nations of the world strive to establish an efficient and effective power sector that will meet up with the ever increasing energy demand in various nations. Although power shortage is predominantly in developing countries, all nations of the world 
encounter electric power transmission and distribution losses, challenges which also affect the available electric power in these nations. Among different nations of the world, the United States tops the 2010 electric power transmission and distribution losses chart with a value of 260.999 billion $\mathrm{kWh}$, where Nigeria occupies the fourty-fifth position with a value of 4.497 billion $\mathrm{kWh}$. Electric power sector of West African countries are characterized by low performance, limited access to electricity and endemic electric power shortages (Gnansounou, 2008). Nigeria, Benin, Ghana, Mali, Togo, and Guinea rely significantly on hydroelectricity for power generation (RCEER, 2005; Gnansounou, 2008) which severely affects the power generation in these nations during drought.

The power demand in nations like Burkina Faso prompted the demand of electricity importation from neighboring countries (RCEER, 2005). Senegal, Mali and Guinea suffered several years of frequent electricity disruptions owing to insufficient electricity generation capacities as well as low reliability of generating plants (Gnansounou, 2008). Senegal which mainly generates its own electricity from oil has experienced frequent power plant outages because of low reliability and fuel procurement difficulties encountered. Outside Africa, India is the worst in electricity deficit as 306 million of Indian population had no access to electricity (Popoola, Ponnle, \& Ale, 2011). Pakistan continual electricity shortages reached crisis proportions in 2013. The nation recorded light outs for at least 10 hours/day in major cities, and up to 22 hours/day in rural areas (Walsh \& Masood, 2013). China, which today has excess available capacity to meet current electricity demand has in the past recorded three periods of nationwide power shortages which covers 1978 - 1996, 2003 - 2006 and 2008 (Shunkun, Lisha, \& Chen, 2013). World Bank reported that over 50 million citizens of countries like Bangladesh, Ethiopia, Congo DR, India and Nigeria lack access to electricity (Popoola, Ponnle, \& Ale, 2011).

\subsection{Residential electricity demand and consumption literatures}

A considerable number of studies have identified determinants of electricity demand both in developed and developing countries. Below is the classification of various studies as they correlate:

Most of the studied literatures adopted development of models in the determination of electricity demand. These studies considered single or a combination of two or more of these variables; real income, electricity price, population growth, structural changes, climatic conditions, urbanization, efficiency improvement using either univariate cointegration approach, multivariate cointegration approach or bounds testing approach in their various studies (Narayan \& Smyth, 2005; Ekpo, Chuku, \& Effiong, 2011; Dincer \& Dost, 1997; Ziramba, 2008 Al-Faris, 2002; Lin, 2003; Sa’ad, 2009; Nasr, Badr, \& Dibeh, 2000; Beenstock, Goldin, \& Nabot, 1999; Donatos \& Mergos, 1991; Engle \& Granger, 1987; Johansen, 1988; Johansen \& Juselius, 1990; Pesaran, Shin, \& Smith, 2001; Choong, ,Yusop, \& Liew, 2005; Halicioglu, 2007).

Socio-demographic factors such as population, urbanization, family size, age distribution, the number of wage earners in the household (Ekpo, Chuku, \& Effiong, 2011; Gladhart, Morrison, \& Zuiches, 1986; Schipper, Barrlett, Hawk, \& Vine, 1989).

Experimental investigation of residential electricity demand for consumption conducted at the disaggregated level (Narayan \& Smyth, 2005; Holtedahl \& Joutz, 2004; Ziramba, 2008; Sa'ad, 2009; Donatos \& Mergos, 1991; Halicioglu, 2007; De Vita, Endresen, \& Hunt, 2006; Zachariadis \& Pashourtidou, 2007; Galindo, 2007; Filippini \& Pachauri, 2004; Hunt, Judge, \& Ninomiya, 2003).

Analysis of electricity demand for accurate and substantial projection and policy analysis was carried out by Ibitoye and Adenikinju (2006) and Babatunde and Shuaibu (2009).

\section{Objective of the study}

Electricity utilization in a household depends on the available appliances and services in which these appliances are engaged in. It is not unusual to expect variation in the factors influencing the demand of 
electricity in different households. Electricity, like other utilities used in households, is not consumed directly by individuals. Rather, it is a service instigated demand from the energy required for running and operating various electrical appliances and equipment in the household (Reiss, 2002). In this view this study was designed to identify electricity utilization features and the effects of power shortage challenges in the residential areas.In text citations

\section{Materials and method}

This research designed to study electric power accessibility and consumption pattern in Obantoko, Ogun State, Nigeria was conducted from May 1 to July 31, 2013. Obantoko, a developing metropolis located at the out skirts of the ancient city of Abeokuta falls within Abeokuta South and Odeda local government areas of Ogun state (Taiwo, Adeogun, Olatunde, \& Adegbite, 2011; Ufoegbune, Orimoloye, Eruola \& Ogunyemi, 2011). The building arrangement in this suburb includes linear, clustered and scattered settlement pattern as was found in different areas with traces of assigned street names in some parts.

A pre tested self-administered questionnaire was used for data collection. The households in this study were selected using multi-staged random sampling technique with no exclusion criteria. The community was divided into two zones and further broken down into ten districts. Each of the districts was represented in the study. The response for each question on the questionnaire accommodated any member of the household with the empiric information for the home. A total of 124 households visited were considered appropriate for this study. Others were turned down due to refusal of various participated households to respond to the majority of the questions and absence of the person who could respond to most of the questions when visited. The questions included, sources of electricity for the home, duration of usage of various sources of power supply, the activities in which the supplied electric power are engaged in, effects of electricity deficit from public sources in the household and preference of power source among the available sources of electricity supply.

The data collected was analyzed in simple frequency and percentage format using Statistical Package for Social Science (SPSS) 16.0 version and presented in table and charts.

\section{Results and discussion}

Obantoko population estimated to be 57,750 people in Ufoegbune, et al. (2011) survey was observed to be experiencing progressive population growth in the last eight years. 62 households representing $50 \%$ of the household participants are tenants, 58(46.8\%) respondents own and live in their houses while 4(3.2\%) household participants live in their family/relative house. The dwelling characteristics of the different households in the area include room(s) 40(32.3\%), flat 64(51.6\%) and duplex 18(14.5\%) apartments.

Almost all the buildings $120(96.8 \%)$ are connected to the national grid. This number contribute to the national population of less than $40 \%$ that are connected to the grid system which, according to Nigerian Energy Policy report, 2003 experience power shortage for over $60 \%$ of the time (Okoye \& Achakpa, 2007). High ownership and operation of private generators 108(87.1\%) demonstrated the epileptic state of power supply in the area. Globally, epileptic power supply is predominant in developing countries like Africa due to poor access and utilization of other sources of power supply and lack of strong political commitments and the implementation of sustainable supporting frameworks. Only 29\% of the population has access to electricity today (ARE, 2014). The same effect is witnessed in Southern Asian countries which accounts for $42 \%$ of the total number of people without access to electricity worldwide, $92 \%$ of whom live in rural areas. It is in record that, none of the countries of South Asia and of the Indian subcontinent have electrification rates above $60 \%$ (with the exception of Sri Lanka, the region's smallest country). India (400 million), Bangladesh (94.5 million), and Pakistan (70.4 million) together still have 564 million people without electricity (ARE, 2014).

The meager electricity supply condition in the area notwithstanding, the vast majority of Obantoko households $82(66.1 \%$ ) rely on public source of electricity supply as their major source of electricity while 
generator serves as backup. This was a different case for 44(33.9\%) households who observed that generator is their major source of electricity as they mostly engage generators in handling electricity demand services in their homes. This observation agreed with Elendu (2013) that unpredictable supply from national grid cause different households to opt for private source of electricity to ensure supplies in their homes. The predominant use of generator as private source of electricity observed is also in line with Kennedy-Darling, Hoyt, Murao, and Ross (2008), that generators running on diesel or gasoline are the common form of off-grid electricity supply. Similarly Idiata, Omoruyi, and Aiwize (2010) found that $60 \%$ of the Nigerian population depends on generators for electricity supply. Tyler (2002) survey also reported 96 to $98 \%$ private generator ownership among rural firms despite the grid connection.

The worst average duration of public electricity witnessed in the last six months were $30 \mathrm{~min} / \mathrm{day}$ and $1 \mathrm{hr} /$ day by $24(19.4 \%)$ and 20(16.1\%) households respectively. There is no household, which observed public power supply above an average of 6hrs/day. This is relatively worse than the national average record of power outages for eight hours per day experienced in the nation (Moyo, 2012). Various views of public electricity supply in Obantoko metropolis varied widely. To 36 households representing $29 \%$ of the household participants, electricity supply in the area is fair. While few $8(6.5 \%)$ it is excellent (Table 1$)$.

In compensation for the much inaccessible quantity and quality of electricity in the metropolis, 54 households representing $43.5 \%$ household participants always run their generators whereas 40 households representing $32.3 \%$ of the household sometimes do. The length of usage recorded among these households ranges from less than one hour (1hr) to $4 \mathrm{hrs}$ and above. The largest proportion of the households $48(38.7 \%)$ use generators for $3 \mathrm{hrs}$ on the daily basis. This was followed by 40(32.3\%) households that run their generator for 4 hrs and above every day. Individual household demand for electricity is a service derived demand from using different number of appliances and equipment (EPSERP, 2009; Ekpo, Chuku, \& Effiong, 2011). Figure 2 showed the various activities in which electricity is involved in, in Obantoko households. Electricity inadequacy in most developing nations of the world instigated self-generation of electricity and hence consequences to the users and the entire globe. These includes the use of relatively inefficient, polluting and health-threatening fuels for their lighting and cooking needs practiced in India (Bairiganjan, Cheung Delio, Fuente, Lall, \& Singh, 2010), use of generator with its attendant noise practiced in Nigeria (Azodo \& Adejuyigbe, 2013) and so on.

Developing nations of the world China, India, Africa and the Middle East, were stated to be the main sources for driving of global energy demand increases in future (Iwayemi, 2008a). This increase witnessed in these nations is attributed to residential power usage given to preferential consideration given in terms of subsidization and supply. Among the services obtainable from electric utilities, lighting was the first and has continued to account for significant source of electricity consumption (IEA, 2006). Globally, almost 1/5th of total electricity generated is consumed by lighting (IEA-ECBCS, 2010). ECN-UNDP (2005) work also showed that lighting is the second major energy-consuming activities in Nigerian households. There was high ownership level of most domestic electrical appliances associated water pumping, dressing, media connection, food preservation, housekeeping, cooking, comfort, illumination and entertainment in all the households.

The other of priority observation made in this study revealed that $21(16.9 \%)$ households mostly engage electric energy for illumination (lighting). This supports the report on global consumption that electric lighting accounted for $99 \%$ of the total light consumption (IEA-ECBCS, 2010). Electricity utility is also involved in the following three groups of activities namely cooking process 12(9.7\%), pumping of water 11(8.9\%) and housekeeping $8(6.5 \%$ (Figure 1$)$. which in its absence are carried out either manually or manual/mechanically. Access to electric energy and electrically operated equipment reduces excessive workload, drudgery encountered and time involved in repetitive manual or manual/mechanical activities such as, washing clothes, pounding foods, grinding or milling food grains, fetching water etc. it was found in studies that static relaxation imposed on individuals especially women in repetitive tasks and bending involved in very frequent household activities causes shoulder pain, neck pain, and degeneration of spine (Bridger, 2008; Suthar \& Kaushik, 2013). In Weiner (1992) and Cometonigeria.com (2011) reports, it was stated that working with the hands above shoulder height 
involved in some household chores like pounding is stressful and have the tendency of increasing risk impingement syndrome development.

The quantity and quality of electrical energy reaching the electricity consumers via distribution system in Nigeria is very poor. Various problems such as limited exploitation of power generation technology, inadequate power generation and high power losses faced by the power sector of the nation translate to voltage variations and electricity deficits witnessed in all sectors. Frequent interruption, especially at the peak of crucial activity instigated $26(21 \%)$ of the household participants to seek alternative source of power supply. To $46(37.1 \%)$ household participants, it is outright power supply outage, 22 households representing $17.7 \%$ of household participants use private source of power supply due to the low voltage of the supplied power from the public source. Whereas all the above factors coerced 14(11.3\%) household participant into private power usage (Figure 2). The sources of electricity supply has impact on quantity and quality of electricity available in the nation. Researches have shown that the nation Nigeria generates her electricity basically from thermal and hydroelectricity despite the enormous potentials available in the nation. This has resulted in the prevailing situation experienced in the nation. Whereas the contemporary developing nation of Asia such as Moroco, which shares the same excellent natural conditions exploits solar, wind, biomass in addition to hydro as sources of power generation in the nation. This significant attainment in the electrification rates in both the rural $(99.6 \%)$ and the urban $(98.2 \%)$ centres were attained from these factors (ARE, 2014).

Table 1

Sources and Access to Electricity

\begin{tabular}{|c|c|c|c|}
\hline Descriptions & & Frequency & Percent \\
\hline \multicolumn{4}{|c|}{ Connection to the national grid } \\
\hline & Yes & 120 & 96.8 \\
\hline & No & 4 & 3.2 \\
\hline \multicolumn{4}{|c|}{ Major source of electricity supply } \\
\hline & National power grid & 82 & 66.1 \\
\hline & Generator & 42 & 33.9 \\
\hline \multicolumn{4}{|c|}{ Ownership of private source of electricity } \\
\hline & Yes & 108 & 87.1 \\
\hline & No & 16 & 12.9 \\
\hline \multicolumn{4}{|c|}{ Type of off grid sources owned } \\
\hline & Generator & 110 & 88.7 \\
\hline & Solar & 2 & 1.6 \\
\hline & Others & 2 & 1.6 \\
\hline \multicolumn{4}{|c|}{ Public power supply rating by different households } \\
\hline & Excellent & 8 & 6.5 \\
\hline & V good & 10 & 8.1 \\
\hline & Good & 28 & 22.6 \\
\hline & Fair & 36 & 29.0 \\
\hline & Poor & 26 & 21.0 \\
\hline & V poor & 16 & 12.9 \\
\hline \multicolumn{4}{|c|}{$\begin{array}{l}\text { Average accessible public electricity in last six } \\
\text { months }\end{array}$} \\
\hline & 30min/day & 24 & 19.4 \\
\hline & $1 \mathrm{hr} /$ day & 20 & 16.1 \\
\hline & $2 \mathrm{hrs} / / \mathrm{day}$ & 10 & 8.1 \\
\hline & $3 \mathrm{hrs} /$ day & 16 & 12.9 \\
\hline & $4 \mathrm{hrs} /$ day & 10 & 8.1 \\
\hline & $5 \mathrm{hrs} /$ day & 14 & 11.3 \\
\hline & $6 \mathrm{hrs} /$ day & 10 & 8.1 \\
\hline & Others not stated & 16 & 12.9 \\
\hline \multicolumn{4}{|c|}{ Private generating plant usage } \\
\hline & Never & 18 & 14.5 \\
\hline & Sometimes & 40 & 32.3 \\
\hline & Always & 54 & 43.5 \\
\hline \multicolumn{4}{|c|}{ Off grid source usage duration } \\
\hline & $<=1 \mathrm{Hr}$ & 4 & 3.2 \\
\hline & $2 \mathrm{hrs}$ & 18 & 14.5 \\
\hline & $3 \mathrm{hrs}$ & 48 & 38.7 \\
\hline & $4 \mathrm{hrs}$ and above & 40 & 32.3 \\
\hline
\end{tabular}

Generally, Ogun State has a tropical climate. The mean monthly temperature ranges from $23^{\circ} \mathrm{C}$ in July to $32^{\circ} \mathrm{C}$ in February, while the rainy season lasts from March to November, followed by dry season 
(Cometonigeria.com, 2011). The temperature of the area makes the use of electric fans and air-conditioners essential for space cooling. The climate condition of an environment affects the inhabitant of the place. In this study, the services of space cooling appliances coupled with entertainment equipment enhances good relaxation and comfort 14(11.3\%). This observation agreed with Munasinghe (1980) that power outage in residential electricity consumers tantamount to loss of leisure. Ventilation concern is not a peculiarity, for example, in Southeast Asian countries like Malaysia, lightweight material like thatch and wood were formerly used in building constructions for proper aeration of the buildings due to hot-humid climatic condition of the nation (Kubota, Jeong, Toe, \& Ossen, 2011).

In this modern dispensation where bricks are predominantly used, the use of air conditioner serves the same purpose of air circulation in the building. This substantially contributes to energy consumption in the residential sector (Kubota et al., 2011). The benefits of electricity as found above in numerous household can turn out to be nightmarish in its absence. The erratic power supply in the Obantoko always and sometimes affect the residential activities of 30(24.2\%) and 64(51\%) of the household participants. In the face of electricity outage, all electrical appliances stop working, no fan, no air condition, no television, etc this hinders many domestic activities. A predominant number among the observed variable held the view that electricity deficit effect on Obantoko dwellers is home discomfort $34(27.4 \%)$.

Fresh and perishable food products such as fish, meats, fruits, and vegetables can be preserved for several days, weeks or even months by cooling or freezing using refrigerators. Altering the environmental conditions the food items, disarm and incapacitate the microorganisms which causes off-flavors and odors, slime production, changes in the texture and appearances, and the eventual spoilage of foods (Stoecker, 1998). Refrigerator use hindrance in Obantoko community results in undue wastage 12(9.7\%) in households. Obvious food wastage in Nigeria is depicted in most refuse dumpsite throughout the nation. Researches (Afon \& Okewole, 2007; Afon, 2007) observed that household waste and refuse dumpsite in Nigeria is characterized by substantial amount of food waste. Ogbonna, Amangabara, and Ekere (2007) echoed that food waste constitute $26.6 \%$ of total waste generated in a major city in Nigeria. Enjoyment/pleasure disruption 11(8.9\%) and Interruption of work 20(16.1\%) are other activities found to be affected by electricity deficit in Obantoko.

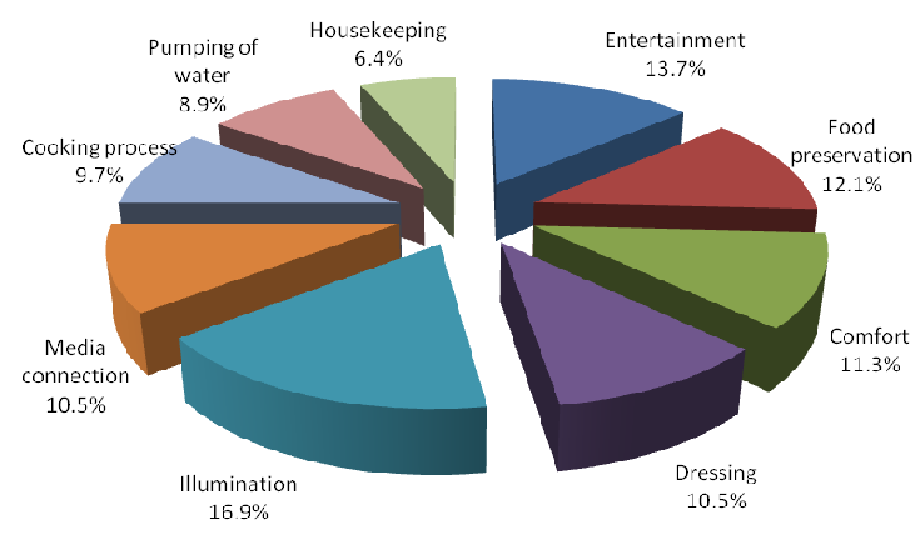

Figure 1. Electricity Consumption Pattern

Frequent operation of private generators in various households constitute nuisance, health concern (Azodo \& Adejuyigbe, 2013) and observed consequential effect on performance 9(7.3\%). Besides the health issues, the running cost of generator which involves refueling, maintenance and repair directly increases the proportion expenditure that goes to energy utilities in 16(12.9\%) household participants. This agreed with Kennedy-Darling et al. (2008) that private generators are more expensive compared with the national power grid (Figure 3). In addition, this findinngs validates Munasinghe, (1980) and Kariuki \& Allan (1996) that residential power outage has direct impact on household earnings and expenditure. Among the various sources of electricity supply available for residential consumption, both on grid (national power grid) and off grid (generator, inverter and 
solar panel) sources, majority of Obantoko residents prefer the public source of electricity supply (national power grid) $84(67.7 \%$ ) due to its relatively cheap cost, load capacity and health assurance.

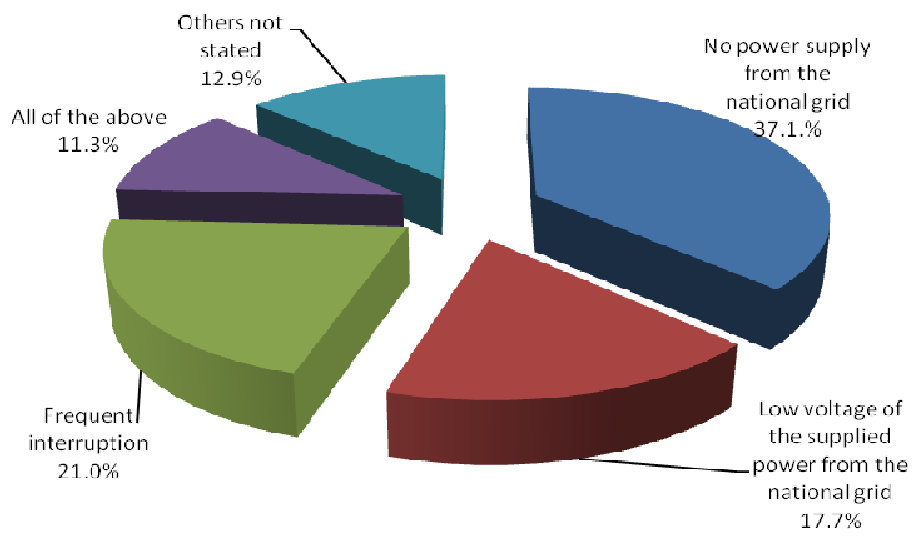

Figure 2. Major Reasons for Using Alternative Power Supply

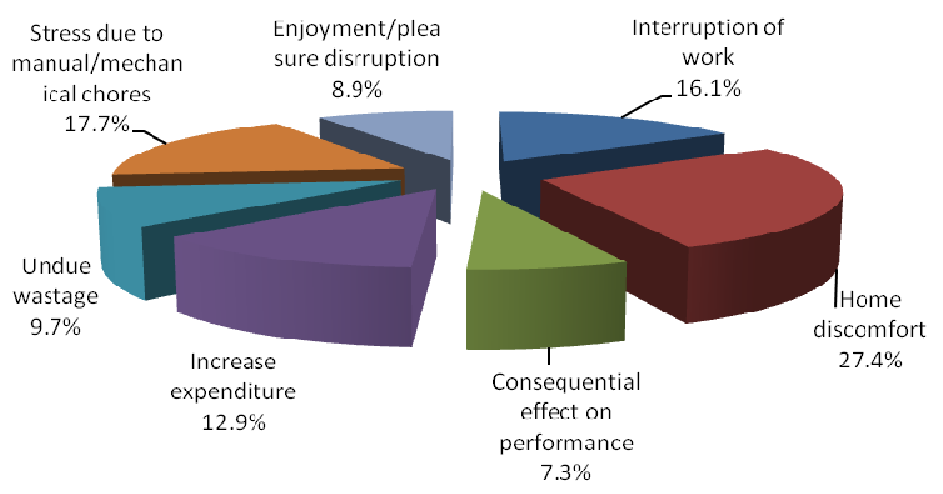

Figure 3. Effects of electricity deficit on households

\section{Conclusions}

The importance of electricity in the residential sector cannot be over emphasized. Virtually all domestic activities in the residential sectors involve the use of electricity. Unfortunately, the much needed electric power supply from the national grid which is also the major source of power supply is marked by its frequent interruption, total blackout, insufficient power and voltage variation. The effect of the electricity deficit in different households includes interruption of work, home discomfort, consequential effect on the performance, increased expenditure, undue wastage, stress due to manual/mechanical household chores and enjoyment/pleasure disruption.

In an attempt to alleviate these challenges, private sources of electricity supply are obtained by different households. Among the various sources of private electricity generation technology available, generator was observed to be the predominant alternative source of power use in the community. This in turn presents another set of problems such as insufficient load capacity, health issues, increased demand for electricity and increased energy utilities expenditure. The issue of electricity deficit is a challenge which demands active participation of both the government and her citizens to address. This could be through prompt payment of bills, avoidance of vandalism of electrical installations, electric energy efficiency and conservation practices, on the part of the citizens ensuring adequate power generation and distribution by exploiting all the available primary sources of 
electricity generation in the country, adopting healthy maintenance culture and doing away with old dilapidated installations on the part of the government.

\subsection{Implications for management and application}

The outcome of constant and consistent power supply to any nation and her citizens cannot be overemphasized. The advantages electricity utilization offers, previously enumerated in this discourse are skeletally experienced in Nigeria due to the erratic nature of the power supply in the nation. The type of appliances used, the energy demand in running those appliances and the irregular usage pattern of different households have been observed to adversely contribute to the power loss in the nation. In the same vein, perceived actions of distribution companies such as frequent interruption of power on crucial processes, improper metering and bills of users' power consumption and many others have speculatively led to boycotting payment of electricity tariff, illegal power connections etc. These in no little measure hamper the demand forecast of electricity consumption determination, accountability, thereby affecting power supply in the nation. Electricity from other private residential sources of power supply is found to be engaged when there is useful need. Each household manages load effect of their appliance, duration of usage and monitor effects of using any appliances on the privately provided alternative source. This implies that the power loss in the residential sector can be revamped via effective regulation and management of electricity utilization in the residential sector.

The regular and proper timing of electricity sources from privately owned alternative sources of electricity by the household gives a clue that proper metering of electricity consumption matched with fair and appropriate tariff will affect the response to the power charges by the residents. Introduction of variation in power bills cost that will help decongest customers' connection and regulate the consumption rate is another step to checking consumption in residential areas. This could be done by associating the bill with the number of grid line connection by each resident. This will help regulate the undue demand and wastage of the supplied power . Launching a rebate for the residential sector, for prudence in electricity consumption was among the policies adopted in Malaysia. This curtailed as much as a million electricity users in Malaysia to desist from electricity consumption profligacy (TNB, 2013). Exempting or waving off charges for a given minimal utilization and charging a very high amount above that bill after substantial improvement must have been achieved is proposed to improve electricity usage in residential sector of the nation. Lastly strict monitoring, unbiased enforcement and treatment of electricity fraud and vandalism issues coupled with severe judgment of defaulter will go a long way in curbing this issue.

\subsection{Limitations and instances for advancement in this area of study}

This study solely depended on the response of the participants as the sources of data for analysis, therefore deliberate turning down and denial of access to some residents for whatever reason was a major limitation to the study as it reduced the number of respondents from the targeted population. The linear, clustered and scattered settlement pattern of study area affected the sample selection. The precise expenditure on power could not be ascertained by the researcher as the majority of the correspondents do not keep accurate record of their total expenditure on electricity. Based on the these challenges, it is suggested that in studies like this the researcher should contact the participant earlier, provide a record sheet which will be collected on a weekly or monthly basis for an extended period (one year or more) for a better and precise response of the correspondents and as well cover different season of the year. In addition the ownership and usage growth of these appliances as proportionate to the income level of each household will provide some basis for further analysis.

\section{References}

Abayomi, W. (2012). Nigeria's power supply security. Retrieved from http://www.myndff.com/PolicyDialogue/Dialogue.aspx?Edition=56

Adegbulugbe, A. O., \& Akinbami, J. F. K. (1995, May). Urban household energy use patterns in Nigeria. In 
Natural Resources Forum (Vol. 19, No. 2, pp. 125-132). Blackwell Publishing Ltd. http://dx.doi.org/10.1111/j.1477-8947.1995.tb00600.x

Adenikinju, A. F. (2003). Electric infrastructure failures in Nigeria: A survey-based analysis of the costs and adjustment responses. Energy policy, 31(14), 1519-1530. http://dx.doi.org/10.1016/S0301-4215(02)00208-2

Abel, A. (2007). An analysis of solid waste generation in a traditional African city: The example of Ogbomosho, Nigeria. Environment and Urbanization, 19(2), 527-537. http://dx.doi.org/10.1177/0956247807082834

Afon, A. O., \& Okewole, A. (2007). Estimating the quantity of solid waste generation in Oyo, Nigeria. Waste Management and Research, 25(4), 371-379. http://dx.doi.org/10.1177/0734242X07078286

Afon, A. O., \& Okewole, A. (2007). Estimating the quantity of solid waste generation in Oyo, Nigeria. Waste Management \& Research, 25(4), 371-379. http://dx.doi.org/10.1177/0734242X07078286

Idris, B. J., \& Ahmad, R. E. (2010, December). Analysis of residential electricity consumption: Is policy reform needed? Paper presented at the Fourth International Borneo Business Conference (IBBC), Universiti Malaysia Sarawak, (International).

Al-Faris, A. R. F. (2002). The demand for electricity in the GCC countries. Energy Policy, 30(2), 117-124. http://dx.doi.org/10.1016/S0301-4215(01)00064-7

Ali-Akpajiak, S. C. A., \& Pyke, T. (2003). Measuring poverty in Nigeria. Oxfam Working Paper, OxfamGB, 274, Oxford.

Anaekwe, E. N. (2010). Investment opportunity in Nigeria. Retrieved from http://www.farriconsultingng.blogspot.com

Alliance for Rural Electrification. (ARE) (2014). Alliance for rural electrification: Energy access in the world facts and scenarios. Retrieved from http://www.ruralelec.org/energy_access_in_the.0.html

Arimah, B. C. (1993). Electricity consumption in Nigeria: A spatial analysis. OPEC review, 17(1), 63-82. http://dx.doi.org/10.1111/j.1468-0076.1993.tb00465.x

Asaolu, T. O., \& Oladele, P. O. (2006). Public enterprises and privatization policy: The Nigerian experience in Nigerian economy: Essays on economic development education. Munich Personal RePEc archive, MPRA, 293 - 394.

Ayodele, A. S. (1999). Improving and sustaining power (electricity) supper for socio-economic development in Nigeria tenth. Paper presented at Abuja Annual Conference.

Azodo A. P., \& Adejuyigbe S. B. (2013). Examination of noise pollution from generators on the residents of Obantoko, Ogun State, Nigeria. Asian Journal of Engineering, Sciences and Technology, 3(1), 31-41.

Babatunde, M. A., \& Shuaibu, M. I. (2009, August). The demand for residential electricity in Nigeria: A bound testing approach. In a paper presented at the conference of the African econometric society, AES, Dakar.

Bairiganjan, S., Cheung, R., Delio, E. A., Fuente, D., Lall, S., \& Singh, S. (2010). Power to the people. Investing in clean energy for the base of the pyramid in India. Washington, Taramani: World Resources Institute. IFMR research. Center for Development Finance.

Beenstock, M., Goldin, E., \& Nabot, D. (1999). The demand for electricity in Israel. Energy Economics, 21(2), 168-183. http://dx.doi.org/10.1016/S0140-9883(98)00005-X

Bhagavan, M. R. (1999). Reforming the power sector in Africa. Zed Books.

Bridger, R. S. (2008). Introduction to Ergonomics. London: Taylor and Francis.

Central Bank of Nigeria. (2009). Central Bank of Nigeria Statistical Bulletin. CBN Press, Abuja.

Choong, C. K., Yusop, Z., \& Liew, V. K. S. (2005). Export-led growth hypothesis in Malaysia: An investigation using bounds test. Sunway Academic Journal, 2, 13-22.

Cometonigeria.com (2011). Ogun State - Gateway State. Retrieved from http://www.cometonigeria.com/search-by-region/south-west/ogun-state/

De Vita, G., Endresen, K., \& Hunt, L. C. (2006). An empirical analysis of energy demand in Namibia. Energy Policy, 34(18), 3447-3463. http://dx.doi.org/10.1016/j.enpol.2005.07.016

Dincer, I., \& Dost, S. (1997). Energy and GDP. International Journal of Energy Research, 21(2), 153-167. http://dx.doi.org/10.1002/(SICI)1099-114X(199702)21:2<153::AID-ER227>3.0.CO;2-Z 
Electric power supply, main source and backing: A survey of residential utilization features

Donatos, G. S., \& Mergos, G. J. (1991). Residential demand for electricity: The case of Greece. Energy Economics, 13(1), 41-47. http://dx.doi.org/10.1016/0140-9883(91)90054-4

Energy Commission of Nigeria. (ECN) (2005). Renewable energy master plan. Abuja.

Energy Commission of Nigeria. (ECN) (2002). National energy policy. Abuja.

Energy Commission of Nigeria and United Nations Development Programme. (ECN-UNDP) (2005). Renewable energy master plan: Final draft report. Retrieved from http://www.iceednigeria.org/REMP\%20Final\%20Report.pdf

Ekpo, U. N. (2010). Public investment and infrastructural development: The case of electric power supply in Nigeria (1970-2004). Unpublished doctoral thesis, University of Uyo, Nigeria.

Ekpo, U. N., Chuku, C. A., \& Effiong, E. L. (2011). The dynamics of electricity demand and consumption in Nigeria: Application of the bounds testing approach. Current Research Journal of Economic Theory, $3(2), 43-52$.

Elendu, I. C. (2013). Sports tourism as an instrument for Nigeria's development in the 21st century: Challenges and way forward. Journal of Education and Practice, 4(4), 143-148.

Energy Information Administration. (IEA) (2006). International energy annual 2006. Retrieved from http://www.eia.doe.gov

Engle, R. F., \& Granger, C. W. (1987). Co-integration and error correction: Representation, estimation, and testing. Econometrica: Journal of the Econometric Society, 55, 251-276. http://dx.doi.org/10.2307/1913236

Filippini, M., \& Pachauri, S. (2004). Elasticities of electricity demand in urban Indian households. Energy Policy, 32(3), 429-436. http://dx.doi.org/10.1016/S0301-4215(02)00314-2

Galindo, L. M. (2005). Short-and long-run demand for energy in Mexico: A cointegration approach. Energy Policy, 33(9), 1179-1185. http://dx.doi.org/10.1016/j.enpol.2003.11.015

Gladhart, P., Morrison, B., \& Zuiches, J. (1986). Energy and Families. East Lansing, Michigan: Institute for Family and Child Study, Michigan State University Press.

Gnansounou, E. (2008). Boosting the electricity sector in West Africa: An integrative vision. International Association for Energy Economics, 17, 23-29.

Halvorsen, B., \& Larsen, B. (1999). Changes in the pattern of household electricity demand over time. Discussion Papers 255, Statistics, Norway.

Halicioglu, F. (2007). Residential electricity demand dynamics in Turkey. Energy Economics, 29(2), 199-210. http://dx.doi.org/10.1016/j.eneco.2006.11.007

Herath, J., Gebremedhin, T., \& Fletcher, J. (2011). An analysis of residential demand for electricity in South Region of the United States. Paper presented at the MCRSA (Mid-Continent Regional Science) Conference.

Herath, J., Gebremedhin, T., \& Fletcher, J. (2011). An analysis of residential demand for electricity in south region of the United States. Mid-Continent Regional Science Association, 13.

Hickling, R. (2006). Electricity consumption in New South Wales: An application of co-integration techniques to energy modelling and forecasting. TransGrid Economics Information Paper, 4.

Holtedahl, P., \& Joutz, F. L. (2004). Residential electricity demand in Taiwan. Energy economics, 26(2), 201-224. http://dx.doi.org/10.1016/j.eneco.2003.11.001

Holtedahl, P., \& Joutz, F. L. (2000). Residential electricity demand in Taiwan. The George Washington University Journal, 3-5.

Hondroyannis, G., Swamy, P. A. V. B. Tavlas, G. S., Hall, S. G. F. (2010). Estimation of parameters in the presence of model misspecification and measurement error. Studies in Non-Linear Dynamics and Econometrics, 14(3), 1-20

Hunt, L. C., Judge, G., \& Ninomiya, Y. (2003). Underlying trends and seasonality in UK energy demand: A sectoral analysis. Energy Economics, 25(1), 93-118. http://dx.doi.org/10.1016/S0140-9883(02)00072-5

Ibitoye, F. I., \& Adenikinju, A. (2007). Future demand for electricity in Nigeria. Applied Energy, 84(5), $492-504$. http://dx.doi.org/10.1016/j.apenergy.2006.09.011

International Energy Agency - Energy Conservation in Buildings and Community Systems. (IEA-ECBCS) 
(2010). Guidebook on energy efficient electric lighting for buildings. Annex 45 - Energy Efficient Electric Lighting for Buildings.

indexmundi.com (2013). Nigeria - Electric power transmission and distribution losses. Retrieved from http://www.indexmundi.com/facts/nigeria/electric-power-transmission-and-distribution-losses

Isola, W. A. (2007). Development in the Nigeria electricity sector. In: Nigeria's development in time perspective: Past, Present and future. Ibadan: NES.

Iwayemi, A. (2008a). Investment in electricity generation and transmission in Nigeria: Issues and options. International Association for Energy Economics, 37-42.

Iwayemi, A. (2008b). Nigeria's dual energy problems: Policy Issues and challenges. International Association for Energy Economics, 53, 17-21.

Johansen, S. (1988). Statistical analysis of co integration vectors. Journal of Economic Dynamics and Control, 12(2), 231-254. http://dx.doi.org/10.1016/0165-1889(88)90041-3

Johansen, S., \& Juselius, K. (1990). Maximum likelihood estimation and inference on co integration - with applications to the demand for money. Oxford Bulletin of Economics and statistics, 52(2), 169-210. http://dx.doi.org/10.1111/j.1468-0084.1990.mp52002003.x

Joskow, P. (2008). Retail electricity consumption. The RAND Journal of Economics, 37(4), 180 - 198.

Kazeem, O. (2013). Power sector privatization and the challenge of powering Nigeria. Retrieved from http://www.workersalternative.com/national-issues/177-ka

Kennedy-Darling, J., Hoyt, N., Murao, K., \& Ross, A. (2008). The energy crisis of Nigeria: An overview and implications for the future. The University of Chicago. Retrieved from http://franke.uchicago.edu/bigproblems/Energy/BP-Energy-Nigeria.pdf

Kariuki, K. K., \& Allan, R. N. (1996). Assessment of customer outage costs due to electric service interruptions: residential sector. IEE Proceedings-Generation, Transmission and Distribution, 143(2), 163-170. http://dx.doi.org/10.1049/ip-gtd:19960192

Kubota, T., Jeong, S., Toe, D. H. C., \& Ossen D. R. (2011). Energy consumption and air-conditioning usage in residential buildings of Malaysia. Journal of International Development and Cooperation, 17(3), 61-69.

Lin, B. Q. (2003). Electricity demand in the people's republic of china: Investment requirement and environmental impact. Economics and Research Department Working Paper Series Number No.37, Asian Development Bank.

Louw, D., Craigwell, R., \& Moore, W. (2008). Price reform and household demand for electricity. Eurojournal, 4, $181-203$.

Makoju, O. (2002). Policy options for the attainment of sustainable electricity supply in Nigeria. Bullion, 26(4), $21-25$.

Mulyono, N. B. (2013). User behavior assessment of household rlectric usage. The Asian Journal of Technology Management, 6(2), 65-71.

Moyo, B. (2012). Do power cuts affect productivity? A case study of Nigerian manufacturing firms. International Business \& Economics Research Journal (IBER), 11(10), 1163-1174.

Munasinghe, M. (1980). Costs incurred by residential electricity consumers due to power failures. Journal of Consumer Research, 361-369. http://dx.doi.org/10.1086/208779

Narayan, P. K., \& Smyth, R. (2005). The residential demand for electricity in Australia: An application of the bounds testing approach to co integration. Energy Policy, 33(4), 467-474. http://dx.doi.org/10.1016/j.enpol.2003.08.011

Narayan, P. K., Smyth, R., \& Prasad, A. (2007). Electricity consumption in G7 countries: A panel co integration analysis of residential demand elasticities. Energy Policy, 35(9), 4485-4494. http://dx.doi.org/10.1016/j.enpol.2007.03.018

Nasr, G. E., Badr, E. A., \& Dibeh, G. (2000). Econometric modeling of electricity consumption in post-war Lebanon. Energy Economics, 22(6), 627-640. http://dx.doi.org/10.1016/S0140-9883(99)00039-0

Nigeria Economic and Power Sector Reform Program. (EPSERP) (2009) Appraisal Report. Retrieved from http://www.afdb.org/fileadmin/uploads/afdb/Documents/Project-and-Operations/Nigeria29.pdf

Odularu, G. O., \& Okonkwo, C. (2009). Does energy consumption contribute to economic performance? 
Electric power supply, main source and backing: A survey of residential utilization features

Empirical evidence from. Nigeria Journal of Economics and International Finance, 1(2), 44-58.

Ogbonna, D. N., Amangabara, G. T., \& Ekere, T. O. (2007). Urban solid waste generation in Port Harcourt metropolis and its implications for waste management. Management of Environmental Quality: An International Journal, 18(1), 71-88. http://dx.doi.org/10.1108/14777830710717730

Oketola, D. (2013). Power generation drops by 1,074MW. Retrieved from http://www.punchng.com/news/power-generation-drops-by-1074mw/

Oketola, D. (2014). Power outage drains consumers' purse. Retrieved from http://www.punchng.com/feature/power-outage-drains-consumers-purse/

Okoye, J. K., \& Achakpa, P. M. (2007). Background study on water and energy issues in Nigeria to inform the national consultative conference on dams and development. Submitted to the Federal Ministry of Agriculture and Water Resources, March.

Idiata, D. J., Omoruyi, S. O., \& Aiwize. E. A. (2010). Sustainable power: Impact of generator driven economy on the environment. Journal of Innovative Research in Engineering and Science 1(1), 55-61.

Okoro, O. I., \& Chikuni, E. (2007). Power sector reforms in Nigeria: Opportunities and challenges. Journal of Energy in Southern Africa, 18(3), 52-57.

Olokooba, S. M., Ibrahim I., \& Abdulraheem-Mustapha, M. A. (2010). Noise pollution: A catalyst to climate change and human health catastrophe. Nigerian Journal of Food, Health and Drug Law, 3(1), 23-38.

George, E. O., \& Oseni, J. E. (2012). The relationship between electricity power and unemployment rates in Nigeria. Australian Journal of Business and Management Research, 2(2), 10-19.

Pelesai, A. N., \& ThankGod, A. O. (2013). The dynamics of demand and supply of electricity in Nigeria. Developing Country Studies, 3(3).

Pesaran, M. H., Shin, Y., \& Smith, R. J. (2001). Bounds testing approaches to the analysis of level relationships. Journal of Applied Econometrics, 16(3), 289-326. http://dx.doi.org/10.1002/jae.616

Popoola, J. J., Ponnle, A. A., \& Ale, T. O. (2011). Reliability worth assessment of electric power utility in Nigeria: Residential customer survey results. Assumption University Journal of Technology 14(3), 217-224.

Reiss, P. C., \& White, M. W. (2002). Household electricity demand, revisited. Stanford University Publication. Retrieved June 6, 2013 from http://www.stanford.edu/ preiss/demand.pdf

Resource Center for Energy Economics and Regulation. (RCEER) (2005). Guide to electric power in Ghana (1st ed.) Institute of statistical, Social and Economic Research. University of Ghana, 1-57.

Sa'ad, S. (2009). Electricity demand for South Korean residential sector. Energy Policy, 37(12), 5469-5474. http://dx.doi.org/10.1016/j.enpol.2009.08.009

Sambo, A. S. (2005). Renewable energy for rural development: The Nigerian perspective. ISESCO Science and Technology Vision, 1, 12-22.

Sanyaolu, H. A. (2008). Electricity power sector reform in Nigeria: Utilizing restructuring and regulatory reform as a means of achieving a more efficient and competitive sector. Thesis (CEPMLP, 2008).

Schipper, L., Bartlett, S., Hawk, D., \& Vine, E. (1989). Linking life-styles and energy use: A matter of time?. Annual review of energy, 14(1), 273-320. http://dx.doi.org/10.1146/annurev.eg.14.110189.001421

Shunkun, Y., Lisha, Z., \& Chen, L. (2013). China Wrestles with power shortages, North China electric power University. Retrieved from http://www.powermag.com/china-wrestles-with-power-shortages/05/01/2013

Emmanuel, S. O., \& Samuel, O. (2012). Energy-cost analysis of alternative sources to electricity in Nigeria. Indian Journal of Science and Technology, 5(1), 1946-1952.

Sule, A. H. (2010). Major factors affecting electricity generation, transmission and distribution in Nigeria. International Journal of Engineering and Mathematical Intelligence, 1(1\&3), 159 -164.

Sule, B. F., Ajao, K. R., \& Ajimotokan, H. A. (2011). A survey of use of electric lamps and energy consumption in residential buildings in selected estates in Ilorin, Nigeria. Energy Engineering, 108(2), 57-68.

Suthar, N. and Kaushik, V. (2013). Musculoskeletal problems among agricultural female workers. Studies on Home and Community Science, 7(3), 145-149

Stoecker, W. F. (1998). Industrial refrigeration handbook. New York: McGraw-Hill Companies, Inc. 
Azodo, A. P.

Taiwo, A. M., Adeogun, A. O., Olatunde, K. A., \& Adegbite, K. I. (2011). Analysis of groundwater quality of hand-dug wells in peri-urban areas of Obantoko, Abeokuta, Nigeria for selected physico-chemical parameters. Pacific Journal Science \& Technology, 12(1), 527-534.

Nasir, M., Tariq, M. S., \& Arif, A. (2008). Residential demand for electricity in Pakistan. The Pakistan Development Review, 457-467.

Tenaga Nasional Berhad. (TNB) (2013). RM20 government subsidy. Retrieved from http://www.tnb.com.my

Tokede, W., \& Okonji, C. (2013). Nigeria, Second worst in electricity - World Bank Report. Retrieved from http://www.mydailynewswatchng.com/nigeria-second-worst-inelectricitysupply/June 5,2013

Tyler, G. (2002). Nigeria-public and private electricity provision as a barrier to manufacturing competitiveness. Africa Region: Findings. World Bank, Retrieved from http://www.worldbank.org/afr/findings/english/find221.pdf

Ubani, O. J., Umeh, L., \& Ugwu, L. N. (2013). Analysis of the electricity consumption in the south-east geopolitical region of Nigeria. Journal of Energy Technologies and Policy, 3(1), 20-31.

Ubi, P. S., Effiom, L., Okon, E. O., \& Oduneka, A. E. (2012). An econometric analysis of the determinants of electricity supply in Nigeria. International Journal of Business Administration, 3(4), 72-82.

Ufoegbune, G. C., Orimoloye, A. O., Eruola, A. O., \& Ogunyemi, I. O. (2011). The economics of water supply management in Obantoko area, Abeokuta, Nigeria. Journal of Geology and Mining Research, 3(6), 153-160.

Uzoma, C. C., Nnaji, C. E., \& Nnaji, M. (2012). The role of energy mix in sustainable development of Nigeria. Continental Journal of Social Sciences, 5(1), 21-29.

Walsh, D., \& Masood, S. (2013). Pakistan faces struggle to keep its lights. Retrieved from http://www.nytimes.com/2013/05/28/world/asia/pakistan-electricity-shortages-reach-crisis-stage.html?r $=0$

Weiner, D. L.(1992). Impingement syndrome: A question of mechanics. Rehab Management, 87- 92.

World Bank. (2003). Making services work for the poor people. world development report 2004. Washington DC: The World Bank and Oxford University Press

Xiaohua, W., \& Zhenmin, F. (2001). Rural household energy consumption with the economic development in China: Stages and characteristic indices. Energy policy, 29(15), 1391-1397.

Yoo, S. H., Lee, J. S., \& Kwak, S. J. (2007). Estimation of residential electricity demand function in Seoul by correction for sample selection bias. Energy Policy, 35(11), 5702-5707.

Zachariadis, T., \& Pashourtidou, N. (2007). An empirical analysis of electricity consumption in Cyprus. Energy Economics, 29(2), 183-198.

Ziramba, E. (2008). The demand for residential electricity in South Africa. Energy Policy, 36(9), 3460-3466. 